\title{
Immunomodulatory Effects of Aloe saponaria on Lipopolysaccharide- Activated RAW 264.7 Macrophages
}

Kim J', Lee $\mathbf{Y}^{1}$, Kong $\mathbf{H}^{1}$, Song $\mathbf{Y}^{1}$, Chong-Kil $L^{2}$ and Kyungjae $\mathrm{K}^{1 *}$

${ }^{1}$ College of Pharmacy, Sahmyook University, Seoul 01795, Korea

${ }^{2}$ College of Pharmacy, Chungbuk National University, Cheongju 28644, Korea

\begin{abstract}
Aloe saponaria (A. saponaria) is composed of a high content of polysaccharides; however, few studies exist on this Aloe species. We analyzed the polysaccharide and protein contents of $A$. saponaria and found them to be $90 \%$ and $3.6 \%$, respectively. A. saponaria reduced nitric oxide production in LPS-stimulated RAW 264.7 macrophages, in addition to decreasing COX-2 mRNA expression. Cytokines, key regulators of the immune response, were specifically regulated in LPS-stimulated RAW 264.7 macrophages treated with $A$. saponaria in a dose-dependent manner, and the expression of co-stimulatory molecules tended to decrease. The concentration of $A$. saponaria crude extract required to exert its immunomodulatory activity is high $(500-2000 \mu \mathrm{g} / \mathrm{mL})$. Further studies will need to purify and optimize the dose required for effective immunomodulation.
\end{abstract}

Keywords: Aloesaponaria; Immunomodulation; Anti-inflammation; Cytokine regulation

\section{Introduction}

Aloe species have been used for thousands of years as traditional herbal medicine around the world. Aloe vera (A. vera L.), A. arborescens (A. arborescens Mill.), and A. saponaria are the primary Aloe species used in nutritional supplement and cosmetics.

Among the Aloe species, numerous studies exist on $A$. vera; however, A. saponaria has rarely been studied. A. saponaria is phenotypically similar to $A$. vera and is primarily cultivated in South Africa for decorative purposes. It grows well in both tropical and desert areas, and unlike $A$. vera, it can withstand a temperature as low as $-7^{\circ} \mathrm{C}$.

The A. saponaria plant is composed of more than $60 \%$ of polysaccharides, which have immunomodulatory activity $[1,2]$. The immunomodulatory activity of Aloe species, including the promotion of lymphocyte proliferation, complement activation, anti-inflammatory activity, anti-ulcer activity, a protective effect for the ultraviolet light or $\mathrm{X}$ - ray, anti-cancer activity, antioxidant activity, and anti-viral activity, is well documented [3-8].

The immunomodulating activity of $A$. vera has been established in several studies [9-14]; however, little is known about the immunomodulatory activity of $A$. saponaria despite its high level of polysaccharides and saponin [15]. In this study, we characterized the immunomodulatory activity of A. saponaria by using RAW 264.7 murine macrophages.

\section{Materials and Methods}

\section{Chemicals}

A. saponaria extract was provided by Friday Meridian (shares) (Seoul, Korea) and analyzed in Carbohydrate Bioproduct Research Center (Seoul, Korea). The sample (SPE_1500_01) is kept in the Immunology Laboratory, College of Pharmacy, Sahmyook University.

\section{Preparation of extracts}

Aloe powder $(150 \mathrm{~g})$ was boiled in $1500 \mathrm{~mL}$ of distilled water for $150 \mathrm{~min}$ and the supernatant was collected. One liter of distilled water was added and heated for $100 \mathrm{~min} ; 500 \mathrm{~mL}$ of the supernatant was then mixed with ethanol (EtOH) to make $70 \% \mathrm{EtOH}$ solution and centrifuged for $5 \mathrm{~min}$. The precipitate was dissolved in distilled water and then lyophilized to store as the final polysaccharide product $(15 \mathrm{~g}$, yield was 10\%) (Figure 1).

\section{Analysis of samples}

Total polysaccharide was analyzed using phenol-sulfuric acid method. After mixing $30 \mu \mathrm{L}$ of sample with $30 \mu \mathrm{L}$ of $5 \%$ phenol, $150 \mu \mathrm{L}$ of sulfuric acid was added and incubated at $37^{\circ} \mathrm{C}$ for $20 \mathrm{~min}$. Absorbance was then measured at $490 \mathrm{~nm}$. The protein content was measured using a BCA kit (Thermo Fisher. No. 23225, Pierce BCA protein assay kit, USA).

\section{Cell culture}

RAW 264.7 macrophages were obtained from the American Type Culture Collection (ATCC). The cells were cultured using standard cell culture method [16].

\section{Measurement of NO}

To activate macrophages, RAW 264.7 cells were treated with lipopolysaccharide (LPS) and co-cultured with A. saponaria at 250, 500,1000 , and $2000 \mu \mathrm{g} / \mathrm{mL}$ for $16 \mathrm{~h}$ at $37^{\circ} \mathrm{C}$ in $5 \% \mathrm{CO}_{2}$. After $16 \mathrm{~h}$, the supernatant of each culture condition was transferred to a new plate and $100 \mu \mathrm{L}$ of $1: 1$ solution mixed the Griess reagent A $(2 \%$ sulfanilamide in $5 \%$ phosphoric acid) and Griess reagent B $(0.2 \%$ naphthylethylenediamine dihydrochloride) was added. Absorbance was measured at $570 \mathrm{~nm}$.

\section{Cytokine assay}

LPS-treated RAW 264.7 macrophages were cultured with $A$. saponaria at $250,500,1000$ and $2000 \mu \mathrm{g} / \mathrm{mL} /$ for $16 \mathrm{~h}$ at $37^{\circ} \mathrm{C}$ in $5 \%$ $\mathrm{CO}_{2}$. After $16 \mathrm{~h}$, inflammatory cytokines IL-1 $\beta$, IL-6, and TNF- $\alpha$ were measured in the supernatant of each group by ELISA kits (eBioScience 88-7013, 88-7064 USA, BD 555268 USA).

*Corresponding author: Kyungjae Kim, College of Pharmacy, Sahmyook University, Seoul 139-742, Korea, Tel: 82233991601; Fax: 82233991617; E-mail: kimkj@syu.ac.kr

Received October 14, 2016; Accepted October 25, 2016; Published October 31 2016

Citation: Kim J, Lee Y, Kong H, Song Y, Chong-Kil L, et al. (2016) Immunomodulatory Effects of Aloe saponaria on Lipopolysaccharide-Activated RAW 264.7 Macrophages. Nat Prod Chem Res 4: 243. doi: 10.4172/2329-6836.1000243

Copyright: ( $2016 \mathrm{Kim} \mathrm{J}$, et al. This is an open-access article distributed under the terms of the Creative Commons Attribution License, which permits unrestricted use, distribution, and reproduction in any medium, provided the original author and source are credited. 


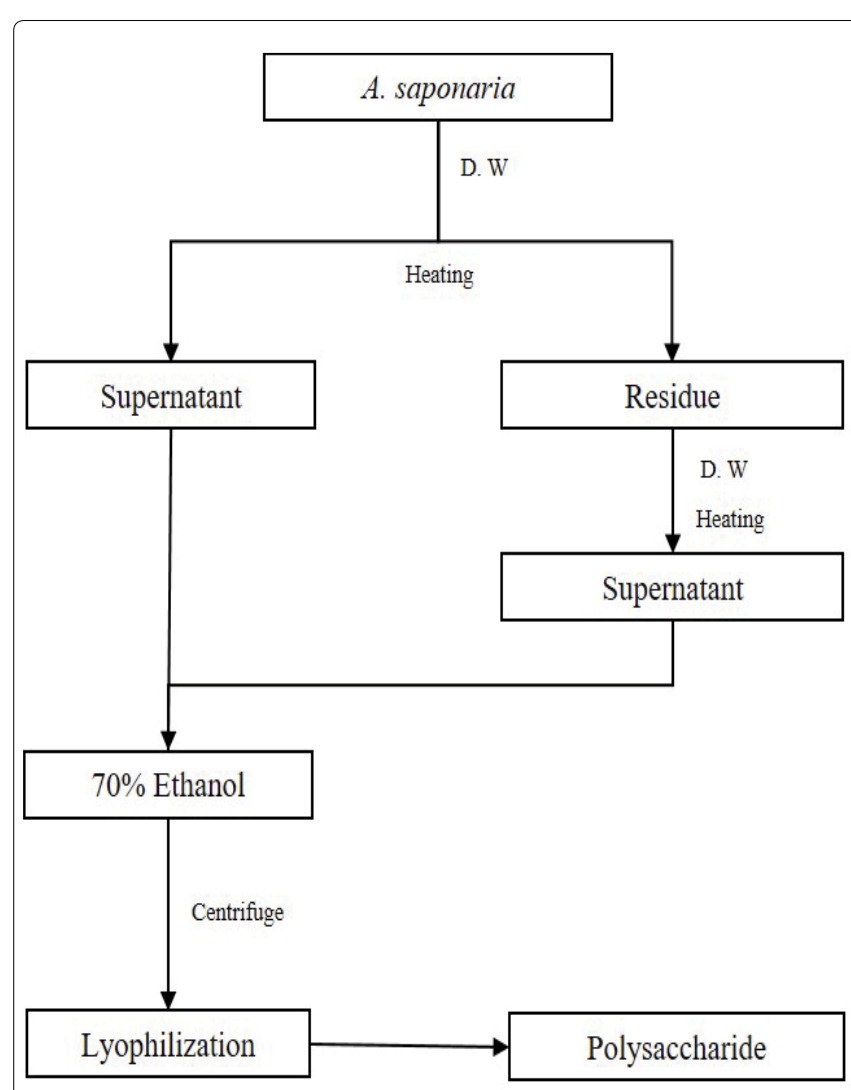

Figure 1: Extraction method from Aloe saponaria.

\section{Isolation of total RNA and reverse transcription polymerase chain reaction ( $R T-P C R)$}

LPS-treated RAW 264.7 macrophages were cultured with $A$. saponaria at $200,400,800$, and $1600 \mu \mathrm{g} / \mathrm{mL}$ for $16 \mathrm{~h}$ at $37^{\circ} \mathrm{C}$ in $5 \%$ $\mathrm{CO}_{2}$. After $16 \mathrm{~h}$, the supernatant was removed and the cells remaining on the plate were treated with RiboEx " (GeneAll, Korea) to extract total RNA. The extracted RNA was then used for quantitative cDNA synthesis. cDNA synthesis was carried out by using an RNA template, Oligo (dT) primer, and the HyperScript ${ }^{\text {" }}$ RT premix (GeneAll, Korea) and by incubating at $42^{\circ} \mathrm{C}$ for $5 \mathrm{~min}$ and at $55^{\circ} \mathrm{C}$ for $60 \mathrm{~min}$. PCR was carried out with Taq polymerase, dNTP, and synthesized cDNA template. PCR incubation conditions were primer-dependent (Table 1). PCR products were analyzed using $0.1 \%$ agarose gel electrophoresis and ethidium bromide (EtBr) staining.

\section{Flow cytometry}

LPS-treated RAW 264.7 macrophages were cultured with $A$. saponaria at $31.2,62.5,125,250$ and $500 \mu \mathrm{g} / \mathrm{mL}$ for $16 \mathrm{~h}$ at $37^{\circ} \mathrm{C}$ in $5 \%$ $\mathrm{CO}_{2}$. The cultured cells were harvested and blocked with purified antimouse CD16/32 antibody. Cells were then labeled with anti-ICAM-1, anti-CD80, and anti-CD86 antibody and fixed. The labeled cells were then analyzed using flow cytometry (FC-500, Beckman coulter). All data are expressed as mean \pm standard deviation.

\section{Statistics}

Statistical significance between groups was determined using Dunnett's test and one-way analysis of variance for repeat measurements. A $p$ value $<0.05$ was considered statistically significant.

\section{Results and Discussion}

\section{Sample analysis}

The polysaccharide and protein content in A. saponaria was measured using the phenol-sulfuric acid method and BCA protein assay, respectively. The protein and saccharide content were found to be $3.6 \%$ and $90 \%$, respectively, and further analysis of these contents yielded the following measurements: fructose $(1.76 \%$; peak 2$)$, rhamnose $(2.82 \%$; peak 3$)$, arabinose (7.48\%; peak 4 ), galactose (14.73\%; peak 6$)$, glucose (43.26\%; peak 7), mannose (29.11\%), and total sugar content (peak 8) (Table 2 and Figure 2).

\section{A. saponaria regulates excessive nitric oxide production}

To determine the state of macrophage activation, we utilized a nitric oxide (NO) assay. Macrophages generate reactive oxygen species and nitrogen species to kill the microorganisms during inflammation; however, if these reactive species are excessively generated, damage to surrounding tissue can occur $[17,18]$.

As shown in Figure 3, NO production from LPS-treated RAW 264.7 macrophages was significantly higher that the control group; however, NO was significantly decreased in RAW 264.7 macrophages treated with $A$. saponaria, in dose dependent manner $(p<0.05)$ (Figure 3 ). Our data suggest that $A$. saponaria regulates excessive inflammation and subsequent tissue damage by suppressing NO production.

\section{A. saponaria promotes an immune response by increasing cytokine production}

LPS-stimulated RAW 264.7 macrophages treated with A. saponaria had a dose-dependent increase in IL- $1 \beta$, IL- 6 , and TNF- $\alpha$ production by ELISA analysis (Figure 4). Macrophages are a crucial innate immune cell that are activated in response to non-specific stimuli, such as inflammatory cytokines including IL- $1 \beta$, IL- 6 , and TNF- $\alpha$. Additionally, IL-1 $\beta$, IL-6, and TNF- $\alpha$ mediate important biological processes in the immune system, including proliferation, activation, and inflammation. IL- $1 \beta$ and TNF- $\alpha$ increase expression of adhesion molecules on vascular endothelial cells to recruit immune cells to a specific site, while IL-6 induces a rapid immune response following injury or infection and increases the production of immunoglobulin $[19,20]$. Our data suggest that $A$. saponaria may enhance the immune response by promoting cytokine production.

\section{A. saponaria suppresses COX-2 mRNA expression}

PCR analysis was utilized to measure mRNA expression of inflammation-related genes. As shown in Figure 5, COX-2 mRNA expression, which is associated with prostaglandin (PG) production, was suppressed by $A$. saponaria treatment while mRNA expression of iNOS and IL- $1 \beta$, IL- 6 and TNF- $\alpha$ remained unchanged $[21,22]$.

Although NO and cytokine production was not regulated by $A$. saponaria at the mRNA level, we found that $A$. saponaria suppressed COX-2 mRNA expression (Figure 5), leading to its potential therapeutic use for pain relief via the regulation of an excessive immune response.

\section{A. saponaria alters the expression of co-stimulatory molecules}

To determine if A. saponaria alters co-stimulatory molecule expression on RAW 264.7 macrophages, we performed flow cytometry. Intercellular cell adhesion molecule-1 (ICAM-1) allows immune cells to move to inflammation sites while CD80/ 86 (B7-1/ B7-2) participate in antigen presenting cell (APC) coupling to T cells. We found that $A$. 
Citation: Kim J, Lee Y, Kong H, Song Y, Chong-Kil L, et al. (2016) Immunomodulatory Effects of Aloe saponaria on Lipopolysaccharide-Activated RAW 264.7 Macrophages. Nat Prod Chem Res 4: 243. doi: 10.4172/2329-6836.1000243

Page 3 of 7

\begin{tabular}{|c|c|c|}
\hline Gene & Forward and Reverse & Nucleotide sequences (5'-3') \\
\hline iNOS & $\mathrm{F}$ & ACGCTGAGTACCTCATTGGC \\
\hline COX2 & $\mathrm{R}$ & AGCTCCTCCCAGGACCACAC \\
\hline $\mathrm{IL}-6$ & $\mathrm{~F}$ & TGACTGTGGGAGGATACATCTCTC \\
\hline $\mathrm{IL}-1 \beta$ & $\mathrm{F}$ & AAGAAGAAAGTTCATTCCTGATCCC \\
\hline & $\mathrm{R}$ & TGCTGGTGACAACCACGGCC \\
\hline TNF- $\alpha$ & $\mathrm{F}$ & GTACTCCAGAAGACCAGAGG \\
\hline & $\mathrm{R}$ & CTCTGCAGACTCAAACTCCAC \\
\hline & $\mathrm{F}$ & CAGGATGAGGACATGACACC \\
\hline & $\mathrm{R}$ & TCCTCTTCAAGGGCCAAGGC \\
\hline & $\mathrm{F}$ & CTTCTCCAGCTGGAGACCC \\
\hline
\end{tabular}

Table 1: Sequence of primers for PCR.

\begin{tabular}{|c|c|c|c|c|c|c|}
\hline No & $\begin{array}{l}\text { Ret.Time } \\
\min \end{array}$ & Peak Name & $\begin{array}{l}\text { Height } \\
\text { nC }\end{array}$ & $\begin{array}{c}\text { Area } \\
\mathrm{nC} C^{*} \min \end{array}$ & Rel.Area \% & $\begin{array}{c}\text { Amount } \\
\text { mg/sample } 1 \mathrm{mg}\end{array}$ \\
\hline 1 & 3.417 & - & 2.046 & 0.251 & 0.31 & - \\
\hline 2 & 3.617 & Fructose & 8.273 & 1.420 & 1.76 & 0.0011 \\
\hline 3 & 6.134 & Rhamnose & 6.650 & 2.275 & 2.82 & 0.0021 \\
\hline 4 & 6.600 & Arabinose & 22.372 & 6.044 & 7.48 & 0.0020 \\
\hline 5 & 7.484 & - & 1.628 & 0.435 & 0.54 & - \\
\hline 6 & 8.150 & Galactose & 38.245 & 11.896 & 14.73 & 0.0046 \\
\hline 7 & 8.884 & Glucose & 97.749 & 34.945 & 43.26 & 0.0202 \\
\hline 8 & 9.884 & Mannose & 51.128 & 23.516 & 43.26 & 0.0180 \\
\hline Total & & & 228.090 & 80.782 & 100.00 & 0.0481 \\
\hline
\end{tabular}

Table 2: Component analysis from Aloe saponaria.

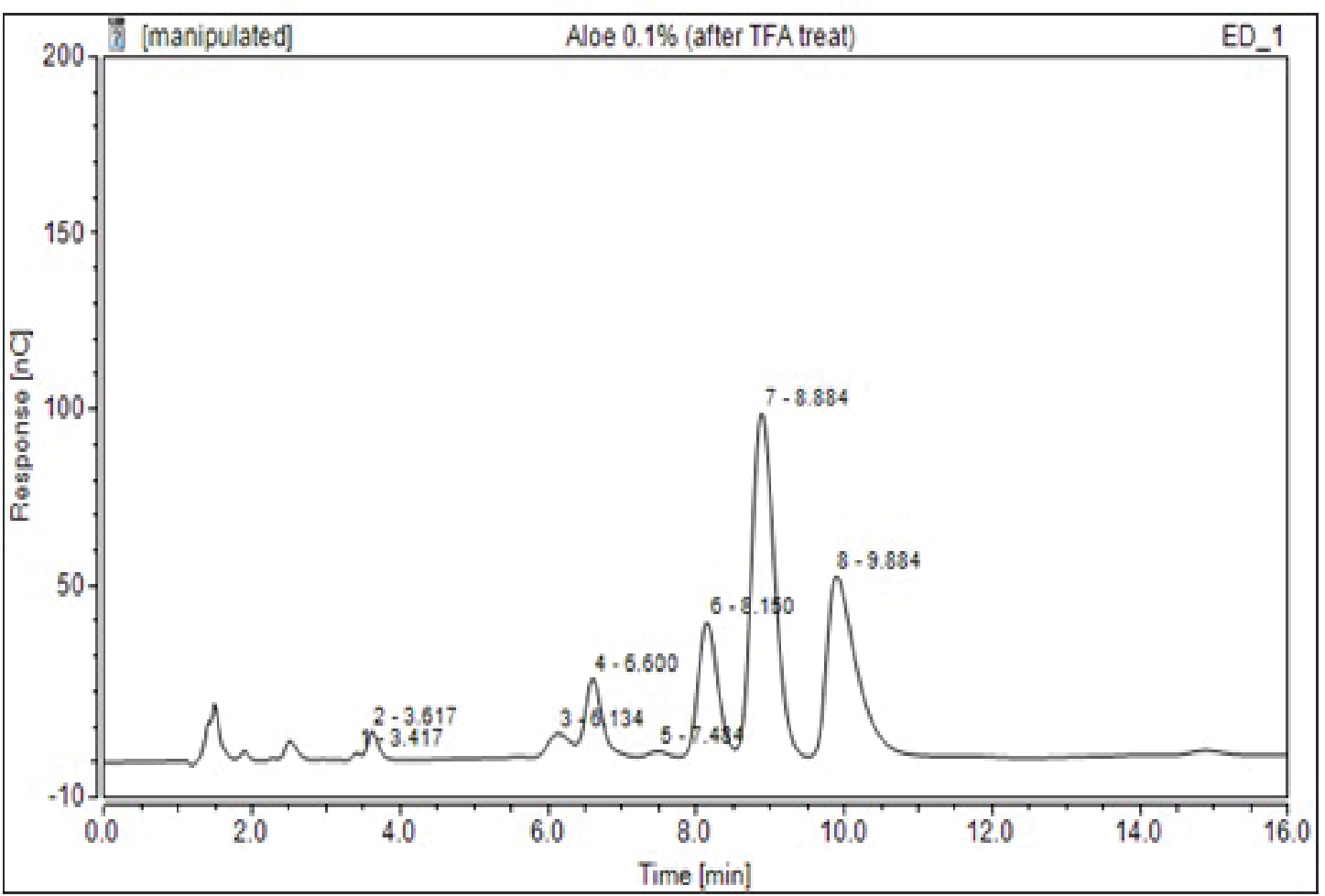

Figure 2: Component analysis from Aloe saponaria. Fucose (peak 2), rhamnose (peak 3), arabinose (peak 4), galactose (peak 6), glucose (peak 7 ) and mannose (peak 8). 


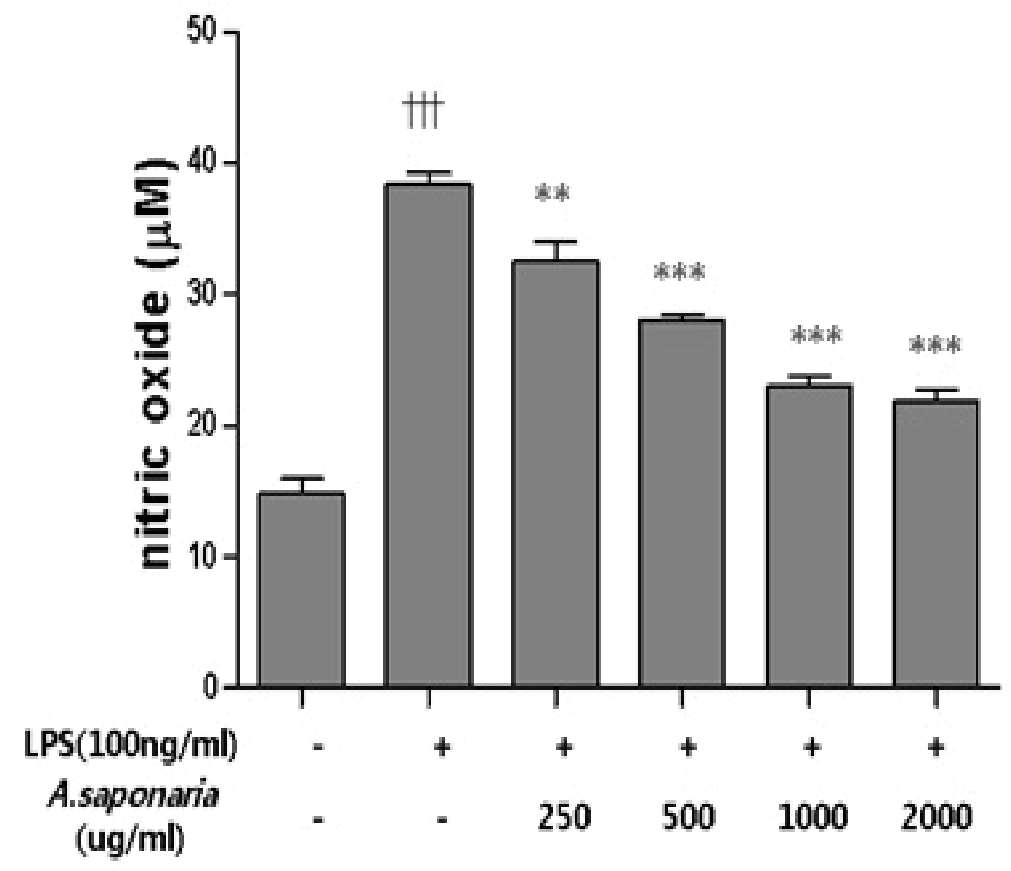

Figure 3: Anti-inflammatory effect of Aloe saponaria. RAW 264.7 cells was treated with lipopolysaccharide and $A$. saponaira. Values are means \pm SD. $\dagger+\dagger p<0.0001$ compared with cells only levels, ${ }^{* *} \mathrm{p}<0.01,{ }^{* * *} \mathrm{p}<0.0001$ compared with LPS only levels.

a.

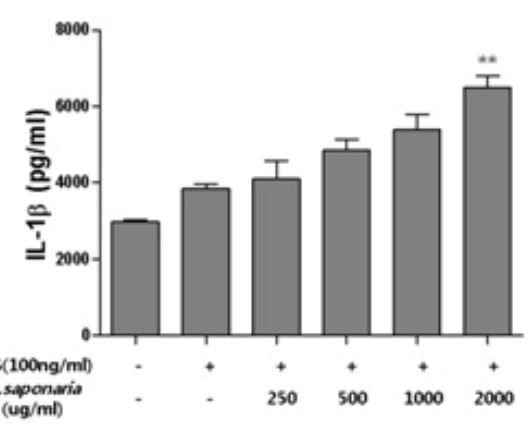

b.

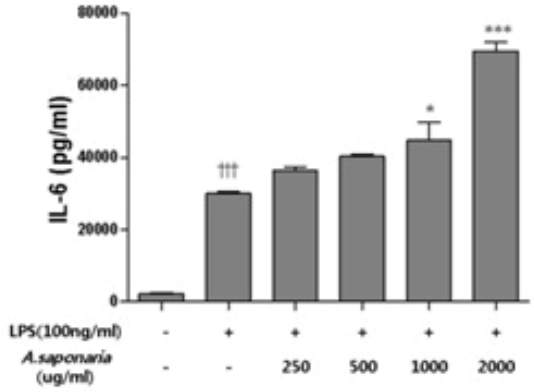

c.

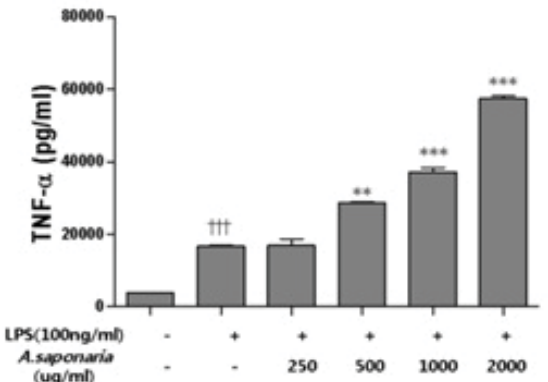

Figure 4: Effect of Aloe saponaria on pro-inflammatory cytokine production. RAW 264.7 cells was treated with lipopolysaccharide and $A$. saponaira. IL-1 $\beta$ (a), IL-6 (b), TNF- $\alpha$ (c) were examined using a commercial ELISA kit. Values are means \pm SD. $\dagger \dagger \dagger p<0.0001$ compared with cells only levels, ${ }^{*} p<0.05$, ${ }^{* *} p<0.01,{ }^{* \star *} p<0.0001$ compared with LPS only levels.

saponaria tended to decrease expression of both ICAM-1 and CD80/86 when treated with LPS (Figures 6 and 7) $[23,24]$.

Macrophages are a major APC that initiates an adaptive immune response by presenting antigen to $\mathrm{T}$ and $\mathrm{B}$ cells. Macrophage upregulation of co-stimulatory molecules is required for $\mathrm{T}$ and $\mathrm{B}$ cell interaction. An unregulated immune response may result from excessive co-stimulatory molecule signal cascades and blocking this initial cell interaction event by downregulating co-stimulatory molecule expression may lead to an appropriate immune response.
Currently, there are both anti-inflammatory and immunomodulatory therapies that utilize co-stimulatory molecule downregulation.

\section{Conclusion}

In this study, we characterized the immunomodulatory activities of A. saponaria. A. saponaria suppressed excessive inflammation by decreasing $\mathrm{NO}$ production and regulating co-stimulatory molecule expression. Further, A. saponaria induced cytokine production in a dose-dependent manner, leading to an appropriate immune response. These results suggest that $A$. saponaria could potentially be utilized 
Citation: Kim J, Lee Y, Kong H, Song Y, Chong-Kil L, et al. (2016) Immunomodulatory Effects of Aloe saponaria on Lipopolysaccharide-Activated RAW 264.7 Macrophages. Nat Prod Chem Res 4: 243. doi: 10.4172/2329-6836.1000243

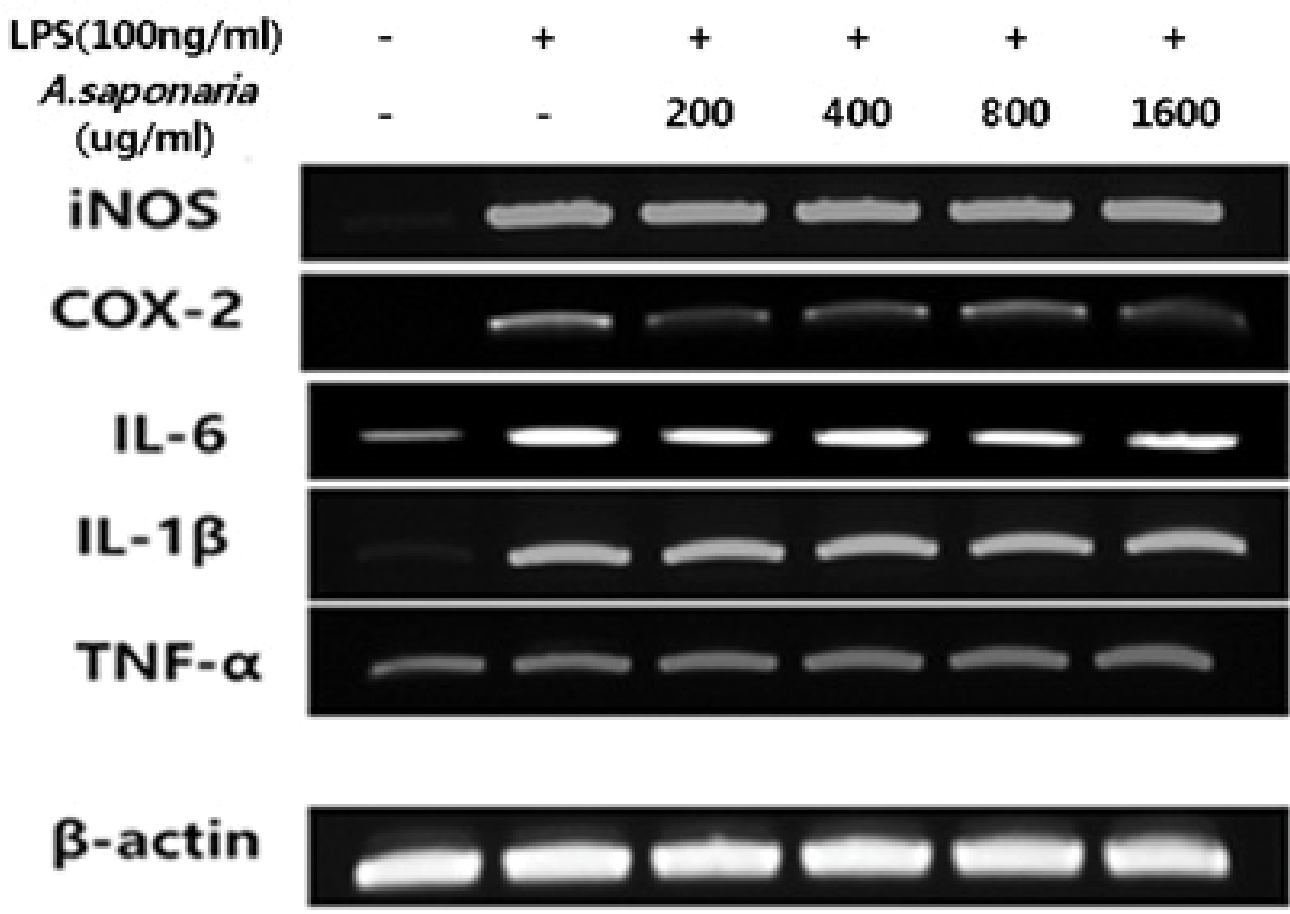

Figure 5: Effect of Aloe saponaria on mRNA expression levels of genes related to inflammation. RAW 264.7 cells was treated with lipopolysaccharide and $A$. saponaira. Three experiments were performed and the similar results were observed.
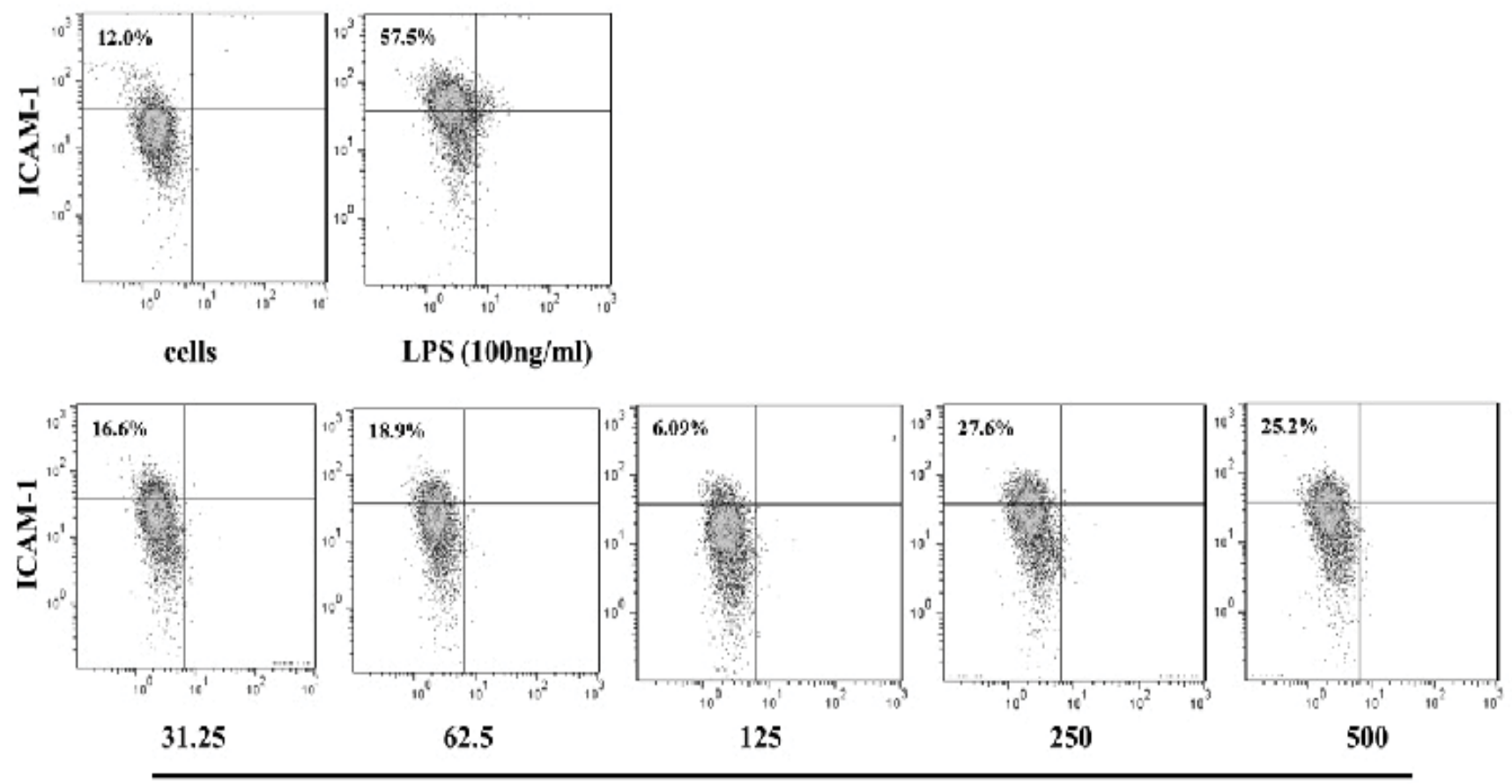

LPS + A. saponaria $(\mathrm{ug} / \mathrm{ml})$

Figure 6: Effects of Aloe saponaria on the expression co-stimulatory molecule. RAW 264.7 cells was treated with lipopolysaccharide and $A$. saponaira. The surface ICAM-1 molecules were labeled and examined using a Flow cytometry. 
Citation: Kim J, Lee Y, Kong H, Song Y, Chong-Kil L, et al. (2016) Immunomodulatory Effects of Aloe saponaria on Lipopolysaccharide-Activated RAW 264.7 Macrophages. Nat Prod Chem Res 4: 243. doi: 10.4172/2329-6836.1000243

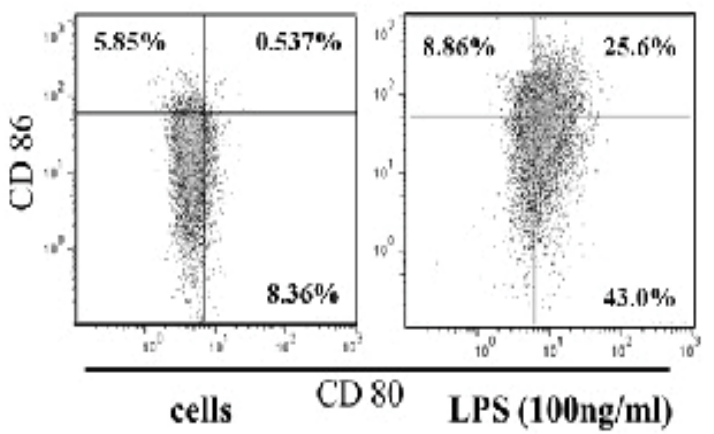

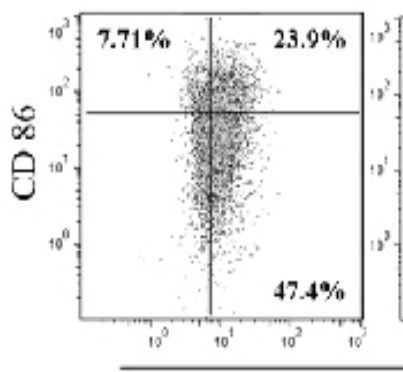

31.25

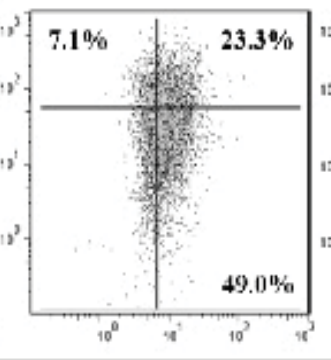

62.5

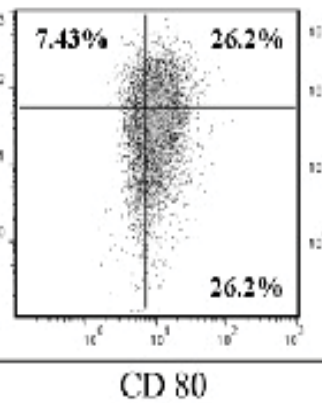

125
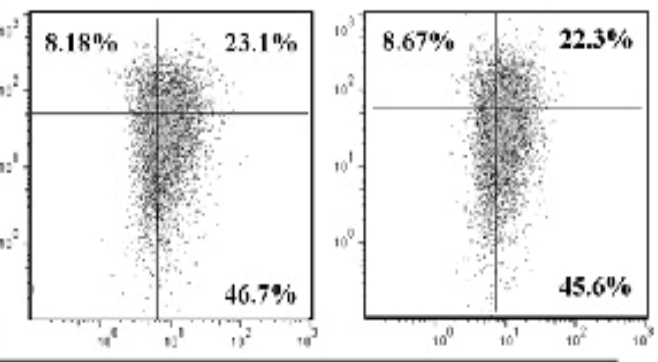

250

\section{LPS + A. saponaria $(\mathrm{ug} / \mathrm{ml})$}

Figure 7: Effects of Aloe. saponaria on the expression co-stimulatory molecule. RAW 264.7 cells was treated with lipopolysaccharide and A. saponaira. The surface CD86 and CD80 molecules were labeled and examined using a Flow cytometry.

as an immune modulator. In the follow-up study, refinement of A. saponaria is of extreme importance and will be performed since the concentration of A. saponaria in this study is quite high compared to other herbal medicines $[25,26]$.

\section{Acknowledgements}

This study was supported by Friday Meridian, Inc. and by Chungbuk National University.

\section{References}

1. Yoo EA, Kim SD, Lee WM, Park HJ, Kim SK, et al. (2008) Evaluation of antioxidant, antinociceptive, and anti-inflammatory activities of ethanol extracts from Aloe saponaria. Haw. Phytother Res 22: 1389-1395

2. Sampedro MC, Artola RL, Murature M, Murature D (2004) Mannan from Aloe saponaria inhibits tumoral cell activation and proliferation. Int Immunopharmacol 4: 411-418.

3. Manna S, McAnalley BH (1993) Determination of the position of the O acetyl group in $\alpha \beta(1 \rightarrow 4)$ mannan (acemannan) from Aloe barbardensis Miller. Carbohyd Res 241: 317-319.

4. Qui Z, Jones K, Wylie M, Jia Q, Orndorff S (2000) Modified Aloe barbadensis polysaccharide with immunomodulatory activity. Planta. Med. 66: 152-156.

5. Saito H, Imanishi K, Okabe S (1989) Effects of Aloe experimental gastric lesions in rats. Yakugaku zasshi. 109: 335-339.

6. Imanishi K (2006) Aloctin A, an active substance of Aloe arborescens Miller as an immunomodulator. Phytother. Res. 7: S20-S22.

7. Sato Y, Ohta S, Shinoda M (1990) Studies on chemical protectors against radiation. XXXI. Protection of effects of Aloe arborescens on skin injury induced by $\mathrm{x}$-irradiation. Yakugaku Zasshi 110: 876- 884

8. Imanishi K, Ishiguro T, Saito H, Suzuki I (1981) Pharmacological studies on plant lectin, Aloctin A. I. Growth inhibition of mouse methylcholanthren-induced fibrosarcoma (Meth A) in ascites form by Aloctin A. Experientia 37: 1186-1187.
9. Ulrich-Lai PM, Engeland WC (2005) Sympathoadrenal activity and hypothalamic-pituitary-adrenal axis regulation. Techniques in the Behavioral and Neural Sciences 15: 419-436.

10. Kovacs KJ, Mikios IH, Bali B (2005) Psychological and physical stressors. In Handbook of stress and the brain. Steckler T, Kalin NH, Reul JMHM (eds.) Part I, Elsevier, pp: 775-792.

11. Davis RH, Donato JJ, Hartman GM, Haas RC (1994) Anti-inflammatory and wound healing activity of a growth substance in Aloe vera. J Am Podiatr Med Assoc 84: 77-81.

12. Rajasekaran S, Sivagnanam K, Subramanian S (2005) Antioxidant effect of Aloe vera gel extract in streptozotocin-induced diabetes in rats. Pharmacol Rep 57: $90-96$

13. Visuthikosol V, Chowchuen B, Sukwanarat $Y$, Sriurairatana S, Boonpucknavig $\checkmark(1995)$ Effect of aloe vera gel to healing of burn wound a clinical and histologic study. J Med Assoc Thai 78: 403-409.

14. Kim K, Kim H, Kwon J, Lee S, Kong H, et al. (2009) Hypoglycemic and hypolipidemic effects of processed Aloe vera gel in a mouse model of noninsulin-dependent diabetes mellitus. Phytomedicine 16: 856-863.

15. Silva MA, Trevisan G, Klafke JZ, Rossato MF, Walker Cl, et al. (2013) Antinociceptive and anti-inflammatory effects of Aloe saponaria Haw on thermal injury in rats. J.Ethnopharmacol 146: 393-401.

16. Han S, Lee JH (2013) Capillarisin inhibits iNOS, COX-2 expression, and proinflammatory cytokines in LPS-induced RAW 264.7 macrophages via the suppression of ERK, JNK, and NF-kappaB activation. Immunopharmacol Immunotoxicol 35: 34-42.

17. Nathan C (1992) Nitric oxide as a secretory product of mammalian cells FASEB J 6: 3051-3064.

18. McCartney-Francis N, Allen JB, Mizel DE, Albina JE, Xie QW, et al. (1993) Suppression of arthritis by an inhibitor of nitric oxide synthase. J Exp Med 178 749-754. 
Citation: Kim J, Lee Y, Kong H, Song Y, Chong-Kil L, et al. (2016) Immunomodulatory Effects of Aloe saponaria on Lipopolysaccharide-Activated RAW 264.7 Macrophages. Nat Prod Chem Res 4: 243. doi: 10.4172/2329-6836.1000243

19. Shin S, Kwon J, Lee S, Kong H, Lee S, et al. (2010) Immunostimulatory Effects of Cordyceps militaris on Macrophages through the Enhanced Production of Cytokines via the Activation of NF-kappaB. Immune Netw 10: 55-63.

20. Feldmann M, Brennan FM, Maini RN (1996) Role of cytokines in rheumatoid arthritis. Annu Rev Immunol 14: 397-440.

21. Seybold VS, Jia YP, Abrahams LG (2003) Cyclo-oxygenase-2 contributes to central sensitization in rats with peripheral inflammation. Pain 105: 47-55.

22. Needleman P, Isakson PC (1997) The discovery and function of COX-2. J Rheumatol Suppl 49: 6-8.

23. Dazzi F, D'Andrea E, Biasi G, De Silvestro G, Gaidano G, et al. (1995) Failure of
B cells of chronic lymphocytic leukemia in presenting soluble and alloantigens. Clin Immunol Immunopathol 75: 26-32.

24. Deeths MJ, Mescher MF (1999) ICAM-1 and B7-1 provide similar but distinct costimulation for CD8+ T cells, while CD4+ T cells are poorly costimulated by ICAM-1. Eur J Immunol 29: 45-53.

25. Kim S, Shin S, Hyun B, Kong H, Han S, et al. (2012) Immunomodulatory Effects of Dioscoreae Rhizome Against Inflammation through Suppressed Production of Cytokine Via Inhibition of the NF-kB Pathway. Immune Nertw 12: 181-188.

26. Lee S, Shin S, Kim H, Han S, Kim K, et al. (2011) Anti-inflammatory function of arctiin by inhibition COX-2 expression via NF-kB pathways. Journal of inflammation 8: 16 